\title{
Transcriptome profiling of Paracoccidioides brasiliensis yeast-phase cells recovered from infected mice brings new insights into fungal response upon host interaction
}

\author{
Milce Costa, ${ }^{1} \dagger$ Clayton L. Borges, ${ }^{1} \dagger$ Alexandre M. Bailão, ${ }^{1}$ \\ Gabriela V. Meirelles, ${ }^{1}$ Yuri A. Mendonça, ${ }^{1}$ Sabrina F. I. M. Dantas, ${ }^{1}$ \\ Fabrícia P. de Faria, ${ }^{1}$ Maria S. S. Felipe, ${ }^{2}$ \\ Eugênia E. W. I. Molinari-Madlum, ${ }^{3}$ Maria J. S. Mendes-Giannini, ${ }^{4}$ \\ Rogério B. Fiuza, ${ }^{1}$ Wellington S. Martins, ${ }^{5}$ Maristela Pereira ${ }^{1}$ \\ and Célia M. A. Soares ${ }^{1}$
}

Correspondence

Célia M. A. Soares celia@icb.ufg.br
Received 27 April 2007

Revised 31 July 2007

Accepted 13 August 2007
${ }^{1}$ Laboratório de Biologia Molecular, Instituto de Ciências Biológicas, Universidade Federal de Goiás, 74001-970, Goiânia, Goiás, Brazil

${ }^{2}$ Laboratório de Biologia Molecular, Universidade de Brasília, Brasília, Brazil

${ }^{3}$ Laboratório de Immunopatologia, Universidade Federal de Goiás, Brazil

${ }^{4}$ Laboratório de Micologia, Universidade Estadual Júlio de Mesquita Filho, Araraquara, São Paulo, Brazil

${ }^{5}$ Laboratório de Bioinformática, Universidade Católica de Goiás, Goiânia, Brazil

Paracoccidioides brasiliensis is a fungal human pathogen with a wide distribution in Latin America. It causes paracoccidioidomycosis, the most widespread systemic mycosis in Latin America. Although gene expression in P. brasiliensis had been studied, little is known about the genome sequences expressed by this species during the infection process. To better understand the infection process, 4934 expressed sequence tags (ESTs) derived from a non-normalized cDNA library from $P$. brasiliensis (isolate $P b 01$ ) yeast-phase cells recovered from the livers of infected mice were annotated and clustered to a UniGene (clusters containing sequences that represent a unique gene) set with 1602 members. A large-scale comparative analysis was performed between the UniGene sequences of $P$. brasiliensis yeast-phase cells recovered from infected mice and a database constructed with sequences of the yeast-phase and mycelium transcriptome (isolate Pb01) (https://dna.biomol.unb.br/Pb/), as well as with all public ESTs available at GenBank, including sequences of the $P$. brasiliensis yeast-phase transcriptome (isolate Pb18) (http:// www.ncbi.nlm.nih.gov/). The focus was on the overexpressed and novel genes. From the total, 3184 ESTs (64.53\%) were also present in the previously described transcriptome of yeast-form and mycelium cells obtained from in vitro cultures (https://dna.biomol.unb.br/Pb/) and of those, 1172 ESTs (23.75\% of the described sequences) represented transcripts overexpressed during the infection process. Comparative analysis identified 1750 ESTs (35.47\% of the total), comprising 649 UniGene sequences representing novel transcripts of $P$. brasiliensis, not previously described for this isolate or for other isolates in public databases. KEGG pathway mapping showed that the novel and overexpressed transcripts represented standard metabolic pathways, including glycolysis, amino acid biosynthesis, lipid and sterol metabolism. The unique and divergent representation of transcripts in the cDNA library of yeast cells recovered from infected mice suggests differential gene expression in response to the host milieu.

†These authors contributed equally to this work.

Abbreviations: EST, expressed sequence tag; KEGG, Kyoto Encyclopedia of Gene and Genomes; sqRT-PCR, semiquantitative RT-PCR.

The GenBank/EMBL/DDBJ accession numbers for the ESTs of Paracoccidioides brasiliensis identified in this study are EST1487-EST6420.

Two supplementary tables listing the overexpressed and novel genes identified during this study and supplementary material describing the EST dataset analysed are available with the online version of this paper. 


\section{INTRODUCTION}

The dimorphic pathogenic fungus Paracoccidioides brasiliensis, the aetiological agent of paracoccidioidomycosis, undergoes a complex transformation; the fungus switches from the mycelial infective form, growing at environmental temperatures, to the yeast form, growing at the mammalian host temperature. The fungus is a pathogen that infects around 10 million individuals in the regions where it is endemic, distributed from Mexico to Argentina (Restrepo et al., 2001). During infection, the host inhales spores from the mycelial form that convert to the budding-yeast form within hours. The disease is characterized by a chronic granulomatous inflammation, and patients may present a broad spectrum of clinical manifestations (Montenegro \& Franco, 1994).

Analysis of the response of $P$. brasiliensis during infection provides a window into the alterations required for the organism to survive in the host milieu. Transcriptional profiles of fungal cells, as well as the relative expression of transcripts in each $P$. brasiliensis phase, have been examined previously (Felipe et al., 2003; Goldman et al., 2003; Marques et al., 2004; Felipe et al., 2005). Transcriptional responses to temperature, mimicking the events of differentiation upon fungal inhalation by the host, have also been studied (Nunes et al., 2005; Bastos et al., 2007). Regarding the isolate Pb01, the subject of the present work, previous in silico electronic subtraction and cDNA microarray studies have provided a view of the fungal metabolism, demonstrating upregulated transcripts and differential expression patterns in yeast phase and mycelium (Felipe et al., 2005).

We have been studying differentially expressed genes in $P$. brasiliensis yeast-form cells upon exposure to host-like conditions. We have previously investigated, by cDNArepresentational difference analysis (cDNA-RDA), the genes overexpressed by $P$. brasiliensis upon infection in a mouse model, as well as upon incubation of yeast cells with human blood (Bailão et al., 2006). Genes putatively related to fungal transport, cell defence and cell wall synthesis/remodelling were particularly upregulated under the host-like conditions analysed. In the present work we sought to amplify our studies of genes potentially related to fungal-host interaction by analysing the transcriptome of yeast-phase cells recovered from livers of infected mice. We analysed 4934 expressed sequence tags (ESTs) generated from a cDNA library. Novel genes as well as upregulated genes, compared to the in vitro transcriptome (https://dna.biomol.unb.br/Pb/) and to the GenBank (http://www.ncbi.nlm.nih.gov/) ESTs, provided insights into metabolic adaptations performed by $P$. brasiliensis during infection. The yeast-phase cells significantly overexpress genes related to glycolysis and ethanol production, fatty acid synthesis and nitrogen metabolism, suggesting a nutrient-rich microenvironment. The overproduction of transcripts from genes represented by these pathways also indicates metabolically active fungal cells that can utilize carbohydrate, lipid and nitrogen sources to generate the necessary compounds and energy for carrying on cellular processes or responding to the surrounding microenvironment.

\section{METHODS}

Maintenance of $\boldsymbol{P}$. brasiliensis and animal infection. $P$. brasiliensis (ATCC MYA-826) was grown for 7 days in BBL Mycosel Agar (Becton Dickinson), supplemented with $10 \%$ fetal calf serum, at $36{ }^{\circ} \mathrm{C}$ for the yeast phase (control cells). Infection of mice was performed as previously described (Bailão et al., 2006). P. brasiliensis yeast-phase cells were harvested from 7-day-old cultures, suspended in sterile PBS ( $7 \mathrm{mM} \mathrm{Na}_{2} \mathrm{HPO}_{4}, 1.5 \mathrm{mM} \mathrm{KH_{2 }} \mathrm{PO}_{4}, 0.137 \mathrm{mM} \mathrm{NaCl}$, $2.7 \mathrm{mM} \mathrm{KCl}, \mathrm{pH} 7.4$ ). Male B.10A mice, 8-12 weeks old, were infected intraperitoneally with $5 \times 10^{6}$ yeast-phase cells. Animals were sacrificed 7 days after infection; livers were removed and homogenized in $5 \mathrm{ml}$ sterile PBS. The cellular suspensions were washed three times, centrifuged at $1000 \mathrm{~g}$ and resuspended in $1 \mathrm{ml}$ PBS. Aliquots $(100 \mu \mathrm{l})$ of the suspension were plated onto BBL Mycosel Agar, supplemented with $10 \%$ fetal calf serum. After 14 days incubation, the cells were recovered and total RNA was extracted. Procedures involving animals and their care were conducted in conformity with the rules of the local ethics committee and international recommendations. Control yeast-phase cells and those recovered from infected tissue were used for RNA extraction.

RNA extractions. Total RNA was extracted under all experimental conditions by the use of Trizol reagent (Invitrogen) according to the manufacturer's instructions. RNAs were used to construct doublestranded cDNAs.

Construction of the cDNA library. The $P$. brasiliensis cDNA library was constructed following the protocols of the SUPERSCRIPT plasmid system with GATEWAY technology for cDNA synthesis and cloning (Invitrogen).

DNA sequencing. The cDNA library was plated to approximately 200 colonies per plate $(150 \mathrm{~mm}$ Petri dish). The colonies were randomly selected and transferred to a 96-well polypropylene plate containing LB medium and grown overnight. Plasmid DNA was isolated and purified. cDNA inserts were sequenced from the $5^{\prime}$ end by employing a standard fluorescence labelling DYEnamic ET dye terminator kit (Amersham Biosciences) with the M13/pUC flanking vector primer. Automated sequence analysis was performed in a MegaBACE 1000 DNA sequencer (GE Healthcare).

EST processing pipeline, annotation and differential expression analysis. EST sequences were pre-processed using the Phred (Ewing \& Green, 1998) and Crossmatch (http://www.genome. washington.edu/UWGC/analysistools/Swat.cfm) programs. Only sequences with at least 100 nucleotides and a Phred quality greater than or equal to 20 were considered for further analysis. ESTs were screened for vector sequences against the UniVec data. The resulting sequences were uploaded to a relational database (MySQL) on a Linux (Fedora) platform, and processed using a modified version of the PHOREST tool (Ahren et al., 2004). The filtered sequences were compared against the GenBank non-redundant (nr) database from the National Center for Biotechnology Information (http:// www.ncbi.nlm.nih.gov/), the Gene Ontology database (http://www. geneontology.org/GO) and InterPro's databases of protein families (http://www.ebi.ac.uk/InterProScan/). The Munich Information Center for Protein Sequences (MIPS) (http://mips.gsf.de/) database was used to assign functional categories and Kyoto Encyclopedia of Gene and Genomes (KEGG) (http://www.kegg.com/) was used to assign Enzyme Commission (EC) numbers and metabolic pathways. 
The database sequence matches were considered significant at $E$ values $\leqslant 10^{-5}$. The clusters were compared to the $P$. brasiliensis transcriptome database (https://dna.biomol.unb.br/Pb/), to select novel and overexpressed genes. For the description of novel genes, sequences were also compared to sequences in GenBank (http:// www.ncbi.nlm.nih.gov/) that also included the ESTs reported previously by Goldman et al. (2003) available in the NCBI database. BLASTX analysis (http://www.ncbi.nlm.nih.gov/BLAST/) (Altschul et al., 1997) was used to find matching sequences with $E$-values $\leqslant 10^{-5}$. With CAP3 assembly (Huang \& Madan, 1999) information stored in the relational database, SQL queries were performed to identify transcripts unique to a specific EST library and/or present in two or more libraries. We have constructed a database to host all the sequence data and the analysis results obtained from this study. The database can be accessed through a web interface at http:// www.lbm.icb.ufg.br/phorestwww/index.php. All the ESTs were submitted to GenBank under accession numbers EST1487-EST6420.

In silico determination of upregulated genes. To assign a differential expression character, the contigs formed with mycelium, control yeast-phase cells and yeast-form cells recovered from infected mice ESTs were statistically evaluated using the method of Audic \& Claverie (1997). Overexpressed genes, compared to the P. brasiliensis transcriptome database (https://dna.biomol.unb.br/Pb/), were determined with a $95 \%$ confidence rate.

Infection of Vero cells with $\boldsymbol{P}$. brasiliensis. Cultures of Vero cells (ATCC CCL81) were maintained in Medium 199 (Sigma-Aldrich) supplemented with $10 \%(\mathrm{v} / \mathrm{v})$ heat-inactivated fetal calf serum. The cells were washed three times in 199 medium and $10^{8}$ yeast-form cells of $P$. brasiliensis were added and incubated for $48 \mathrm{~h}$ at $36{ }^{\circ} \mathrm{C}$, as described previously (Mendes-Giannini et al., 2006). The cells were washed three times in PBS followed by incubation in PBS containing trypsin $(0.2 \%)$ and EDTA $(0.02 \%)$ for $30 \mathrm{~min}$ for total monolayer removal. The cells were centrifuged $(1400 \mathrm{~g}, 5 \mathrm{~min})$ and the pellet was recovered for further RNA extraction.

PCR analysis of genomic DNA of $\boldsymbol{P}$. brasiliensis. The presence of novel genes was initially assayed by PCR of genomic DNA of $P$. brasiliensis yeast-form cells, prepared according to standard methods. PCR of selected genes was performed with specific sense and antisense primers, as described in Table 1.
Semiquantitative RT-PCR analysis of $\boldsymbol{P}$. brasiliensis regulated genes. Total RNAs were obtained from control yeast-form cells from a different batch of infected animals to those used for the construction of the cDNA library and from fungal yeast forms infecting Vero cells. Single-stranded cDNAs were synthesized. PCRs were performed using cDNAs as templates in $30 \mu \mathrm{l}$ reaction mixtures containing specific primers (Table 1). PCR conditions were: $95{ }^{\circ} \mathrm{C}$ for $1 \mathrm{~min}, 95{ }^{\circ} \mathrm{C}$ for $30 \mathrm{~s}$, annealing at $55-65{ }^{\circ} \mathrm{C}$ for $2 \mathrm{~min}, 25-35$ cycles at $72{ }^{\circ} \mathrm{C}$ for $1 \mathrm{~min}$, final extension at $72{ }^{\circ} \mathrm{C}$ for $7 \mathrm{~min}$. The annealing temperature and the number of PCR cycles were optimized for each experimental condition to ensure exponential amplification in semiquantitative RT-PCR (sqRT-PCR) analysis. Amplicons were analysed by agarose gel electrophoresis $(1 \%)$. The analyses of relative differences were performed using Scion Image Beta 4.03 software (http://www. scioncorp.com/pages/scion_image_windows.htm).

\section{RESULTS}

\section{Overview of ESTs from $P$. brasiliensis yeast-form cells recovered from infected mice}

The purpose of this study was to identify a set of upregulated genes, as well as novel genes, expressed by $P$. brasiliensis in a mouse model of infection, as a first step towards a large-scale screen for genes associated with fungal pathogenesis. A total of 4934 high quality sequences were obtained and used to establish an EST database consisting of 1602 unique sequences from $P$. brasiliensis yeast-phase cells recovered from livers of infected mice (http://www.lbm.icb.ufg.br/ phorestwww/index.php). A total of 1172 sequences $(23.75 \%$ of the total) corresponded to overexpressed sequences when compared to the transcriptome of in vitro-cultivated $P$. brasiliensis yeast-form cells. A total of 1750 sequences ( $35.47 \%$ of the total) had no homology to sequences found previously in P. brasiliensis, as demonstrated by comparative analysis to the ESTs from the $P$. brasiliensis transcriptomes described elsewhere (Felipe et al., 2005; Goldman et al. 2003). All sequences were arranged into

Table 1. Oligonucleotide primers used in PCR and or sqRT-PCR

\begin{tabular}{|c|c|c|c|}
\hline Sequence name & Forward primer $\left(5^{\prime} \rightarrow 3^{\prime}\right)$ & Reverse primer $\left(5^{\prime} \rightarrow 3^{\prime}\right)$ & $\begin{array}{l}\text { Size of amplified } \\
\text { product (bp) }\end{array}$ \\
\hline Indigoidine synthase A-like protein (indA) & ATAGCCGACCTGACTGAACT & CCCTCTCTTGAATGCCGTAT & 323 \\
\hline Oligopeptide transporter protein $(o p t)$ & CAAGCGACTGGAGCAACCGA & CTGCGTTGTGTATTGAAGCCG & 228 \\
\hline Rho guanyl nucleotide exchange factor (gef) & TCTCCCAAACGCTGAACACT & ATCAATCGTCCAGAGGGTAG & 325 \\
\hline Oxidation resistance 1 protein $($ oxr 1$)$ & TCCCAGTCCGAATCTCAATC & CTGCTCGCAAATGCCTTACA & 410 \\
\hline Glucokinase $(g l k)$ & GGTCTGGCGTAAATGTGCAC & GGCTGGTGAATTTGTATCGC & 368 \\
\hline Carbonic anhydrase $(c a)$ & ACACGGGACGAAAGCACTAT & AAACCTGCTGGCATTGTGGC & 322 \\
\hline Myosin 2 isoform (myo2) & TGGCGAAATCATGAAAGCGG & GGCGGGCACAGCATGGTAA & 291 \\
\hline Telomerase reverse transcriptase $($ tert $)$ & TGGGAACATCATCGACACGT & GGCTGCCATAGTCCGAATAA & 343 \\
\hline Poly(A) polymerase 1 ( $p a p 1)$ & TCGCGATCCCATACAACCTT & GACGAGTTGGACCTTCACCT & 345 \\
\hline Orotate phosphoribosyltransferase (ura5) & CAGCTGCAGTCGTTACAACA & GGGTTGGAGGAGAGGAAAG & 249 \\
\hline Patatin-like serine hydrolase (pat) & GGATCATGTGTCTGCGCTAC & GGGAAGAGATCGATTTGAGG & 468 \\
\hline Squalene synthase $(\operatorname{erg} 9)$ & GCTGACTATTGCCGAAAGG & GTTCGAGGGTTGCAATGGC & 460 \\
\hline Ribosomal L34 protein (l34) & ATTCCTGCCCTCCGACCC & CCCGCCATTCTCGTCCCGC & 750 \\
\hline $\begin{array}{l}\text { Glyceraldehyde 3-phosphate dehydrogenase } \\
(\text { gapdh) }\end{array}$ & CAGACAGCTGCATCTTCT & ТСТСТСТСТTССТСTTGCG & 1106 \\
\hline
\end{tabular}


1041 contigs and 561 singletons that represented different transcripts. The complete dataset is available as supplementary material with the online version of this paper.

\section{Functional annotation and analysis of sequences}

The EST sequences were compared to the non-redundant database from NCBI using the BLASTX algorithm (Altschul et al., 1997). ESTs and UniGenes (clusters containing sequences that represent a unique gene) were given a putative assignment according to the classification developed by MIPS (Fig. 1). The major MIPS categories represented included metabolism, cellular transport, energy, cell cycle and DNA processing, cell rescue and virulence, protein synthesis and protein fate. A high proportion of the ESTs (41.12\%) exhibited sequence similarity only to genes of unknown function or encoding hypothetical proteins, which may reflect the specialization of these structures in P. brasiliensis.

\section{Identification of overexpressed genes by in silico EST subtraction and of novel transcripts in yeast- form cells recovered from infected mice}

To select transcripts upregulated during the infection process of $P$. brasiliensis isolate $P b 01$, we performed comparative analysis of the ESTs with the transcriptome database generated previously with in vitro-grown mycelium and yeast-phase cells (Felipe et al., 2005). The distribution of the overexpressed ESTs, representing 1172 sequences, is presented in Supplementary Table S1, available with the online version of this paper. Analysis of the MIPS categories showed a statistically significant difference between the in vitro-cultured cells and the infectious library for several biological processes. The results indicated that the overexpressed genes identified by comparative analysis encoded enzymes from several metabolic pathways, transcription factors and membrane transporters, among other protein. The data illustrate the functional diversity of these overexpressed ESTs, with particular functional categories dominating the analysis.

To identify novel transcripts expressed during the infection process of $P$. brasiliensis we performed comparative analysis of the generated ESTs (http://www.lbm.icb.ufg.br/ phorestwww/index.php) with the transcriptome database (https://dna.biomol.unb.br/Pb/) and with the ESTs and complete sequences in GenBank (http://www.ncbi.nlm.nih. gov/). The distribution of the novel ESTs, representing 1750 sequences, is presented in Supplementary Table S2, available with the online version of this paper. The ESTs were classified into 16 groups of functionally related genes, with sequences encoding enzymes involved in cell metabolism

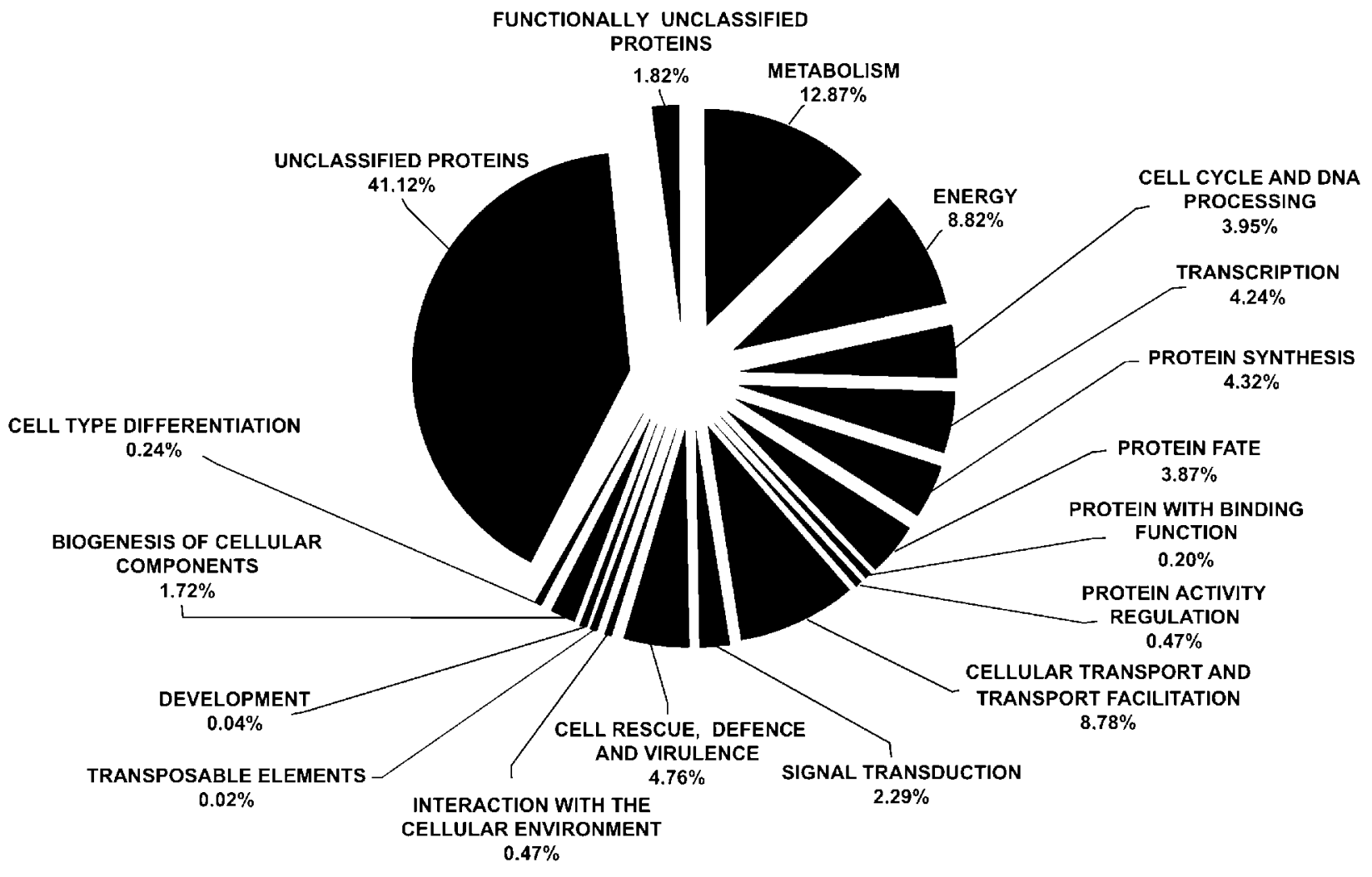

Fig. 1. Overview of ESTs from the $P$. brasiliensis transcriptome. Classification of the ESTs based on $E$-value and according to the functional categories of the MIPS functional annotation scheme. 
and energy, transport facilitators and transcription factors dominating the analysis.

\section{Highly redundant genes}

Table 2 lists the 50 most abundant ORFs in the EST collection in the present transcriptome. A total of 50 contigs containing 892 ESTs were highly redundant. This accounted for $18.08 \%$ of the total high-quality ESTs. The minimum number of ESTs that made up these most highly redundant contigs was 10. A large number of ESTs encoded membrane transporters, stress-related proteins, molecules related to nitrogen metabolism or enzymes of carbohydrate and lipid metabolism. Most of the abundant transcripts represent overexpressed genes. Included in the highly abundant transcripts are some that have been described previously as upregulated in yeast-form cells when compared to mycelia, such as those encoding alcohol dehydrogenase, aromatic-Lamino acid decarboxylase and isocitrate lyase (Felipe et al., 2005). The presence of novel P. brasiliensis genes in the highly abundant category, such as those encoding carbonic anhydrase and glucokinase, was noted.

\section{Overview of $P$. brasiliensis infective transcriptome: pathway analysis based on the KEGG classification}

EC numbers were used to judge which sequences pertained to a specific pathway. A total of 320 unique sequences including 265 contigs and 55 singlets accounted for $19.97 \%$ of unique sequences and matched enzymes with an EC number. The distribution of novel and upregulated ESTs was examined (Table 3). Based on the KEGG classification, it was observed that novel and overexpressed transcripts were predominantly involved in carbohydrate, amino-acid, energy and lipid metabolism.

\section{Most relevant aspects of metabolic pathways upregulated during the infection process}

Analysing the data presented in Tables 1 and 2, and supplementary material, some insights were obtained into the metabolic features of $P$. brasiliensis yeast-form cells during the infection process. The metabolic features are summarized in Table 4. Among the processes that appear to be increased in yeast-form cells during the infection process, carbohydrate, lipid and nitrogen metabolism showed the most significant changes.

\section{Metabolism of carbohydrates}

Homologues of nine genes related to carbohydrate synthesis/degradation were identified as novel or overexpressed in the UniGene set (Table 4). Transcripts encoding acylphosphatase, quinoprotein alcohol dehydrogenase, glucokinase and phosphoglycerate mutase, potentially related to the anaerobic metabolism of glucose, were identified. Glycogen phosphorylase I might be required for the mobilization of glycogen, providing glucose for energy production. D-Ribose-5-phosphate ketol isomerase would allow oxidative reactions to continue by the production of hexose phosphates. Systems for the transport of sugars, MFS1, MFS2 and PTS, are also overexpressed, putatively providing additional fuel for the oxidative reactions.

\section{Lipid metabolism}

Genes involved in lipid metabolism that were overexpressed or represented novel transcripts in P. brasiliensis are summarized in Table 4 . The overexpressed malic enzyme is required for the transport of acetyl groups to the cytosol and provides NADPH for lipid synthesis. Carbonic anhydrase, which could provide bicarbonate for the synthesis of malonyl-CoA by acetyl-CoA carboxylase and is a key regulatory enzyme in fatty acid metabolism, is overexpressed during the infection process. Fatty acyl CoA synthase is also overexpressed in the transcriptome analysed, reinforcing the suggestion of active synthesis of lipids by yeast cells during infection.

The synthesis/remodelling of membrane components, including ergosterol, might be induced. Transcripts encoding MBOAT, a putative acetyltransferase involved in phospholipid biosynthesis/remodelling, a patatin-like protein with putative phospholipase $\mathrm{A}_{2}$ activity and a phospholipase A1 are overexpressed under infection conditions. Delta- 9 fatty acid desaturase (Ole1), an overexpressed gene, could introduce a double bond into saturated fatty acyl-CoA substrates, giving rise to monounsaturated fatty acids. The transcript encoding sterol $C$-methyltransferase, ERG6, which is related to the biosynthesis of ergosterol, is upregulated; a novel transcript encoding a homologue of squalene synthase, ERG 9, catalysing the first committed step in the sterol biosynthesis pathway, was also detected. The synthesis of sphingolipids could be increased by overexpression of delta-8-sphingolipid desaturase.

\section{TCA and the glyoxylate cycle and energy production}

The glyoxylate cycle could be induced in yeast-form cells during the infection process. The isocitrate lyase gene is upregulated. Genes with functions associated with the glyoxylate cycle were also induced, such as the gene encoding hydroxymethyl glutaryl-CoA lyase, which could provide acetyl-CoA. The transport of acetyl-CoA into the mitochondria might be upregulated. Carnitine acetyltransferase and carnitine/acylcarnitine translocase are required for the transport of acetyl-CoA from the peroxisomes into the mitochondria. Components of the classical pathway of oxidative phosphorylation are also induced.

\section{Nitrogen metabolism}

Comparison of our EST data with KEGG revealed that many overexpressed transcripts encode proteins that are 
Table 2. Identification of the highly abundant clusters ( $\geqslant 10$ reads) of $P$. brasiliensis transcripts

50 ORFs representing the highest number of ESTs in the cDNA library are listed.

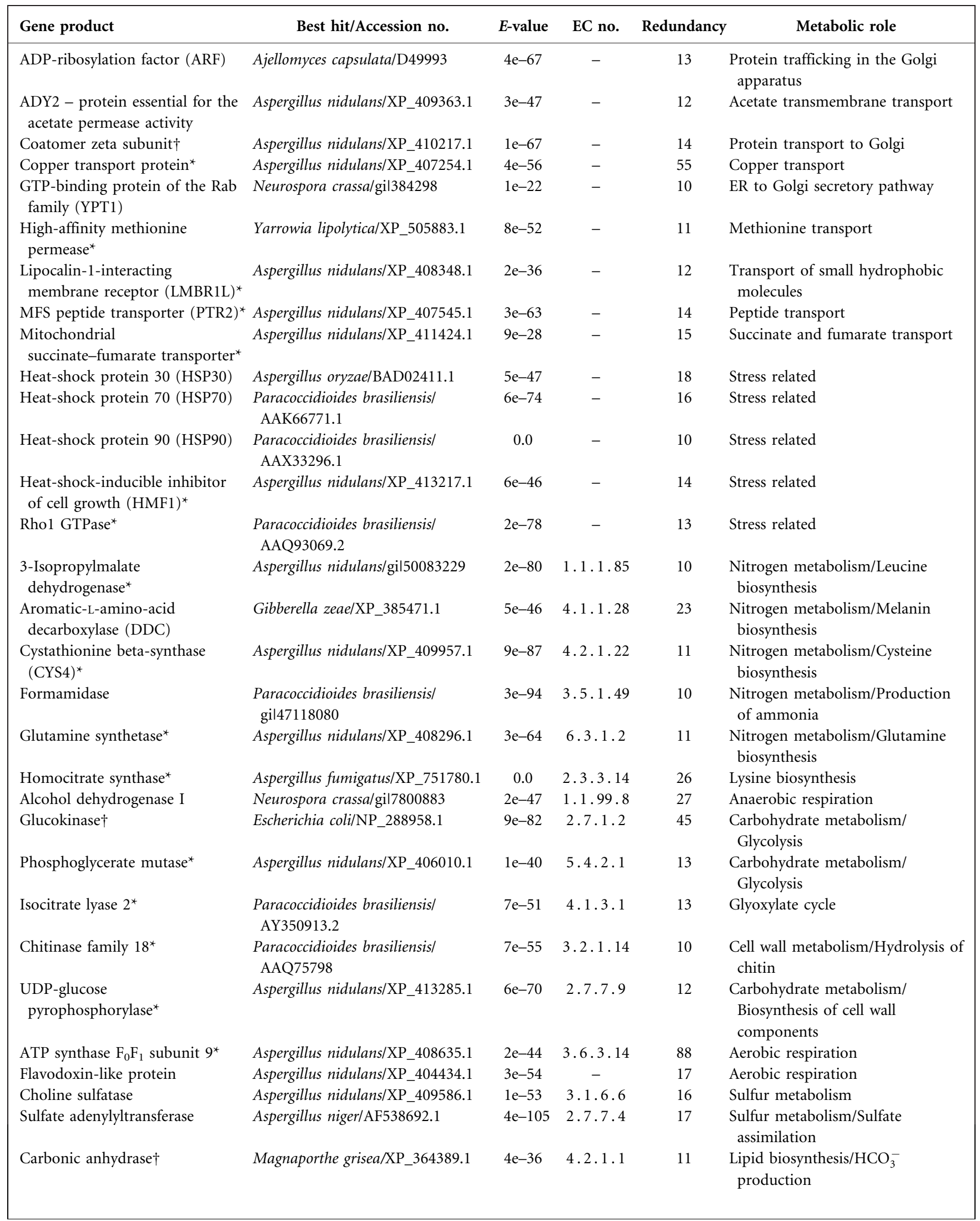


Table 2. cont.

\begin{tabular}{|c|c|c|c|c|c|}
\hline Gene product & Best hit/Accession no. & $E$-value & EC no. & Redundancy & Metabolic role \\
\hline $\begin{array}{l}\text { Delta-9-fatty acid desaturase } \\
(\text { OLE1 })^{*}\end{array}$ & Ajellomyces capsulatus/gil46395695 & $7 e-102$ & 1.14 .19 .1 & 22 & $\begin{array}{l}\text { Lipid metabolism/ } \\
\text { Monounsaturated fatty acid } \\
\text { biosynthesis }\end{array}$ \\
\hline Malic enzyme & Aspergillus nidulans/XP_410305.1 & $2 \mathrm{e}-89$ & 1.1 .1 .40 & 11 & Related to fatty acid biosynthesis \\
\hline $\begin{array}{l}\text { Long-chain base-responsive } \\
\text { inhibitor of protein kinases } \\
\text { Pkh1p and Pkh2p (PIL1)* }\end{array}$ & Aspergillus nidulans/XP_409354.1 & $7 e-45$ & - & 11 & Protein activity regulation \\
\hline $\begin{array}{l}\text { Ornithine decarboxylase } \\
\text { antizyme }\end{array}$ & Emericella nidulans/AF291577.1 & $1 e-26$ & - & 10 & Proteasomal ubiquitin degradation \\
\hline $\begin{array}{l}\text { Protein-L-isoaspartate } \\
\text { (D-aspartate) } \\
\text { O-methyltransferase } 1^{*}\end{array}$ & Aspergillus nidulans/XP_407601.1 & $5 e-55$ & 2.1 .1 .77 & 14 & $\begin{array}{l}\text { Protein fate/Repair of } \beta \text {-aspartyl } \\
\text { linkages }\end{array}$ \\
\hline $\begin{array}{l}\text { Peptidyl-prolyl cis-trans } \\
\text { isomerase }\end{array}$ & Neurospora crassa/gil38567156 & $1 e-61$ & 5.2 .1 .8 & 17 & $\begin{array}{l}\text { Protein fate/Regulation of RNA } \\
\text { transcription and splicing }\end{array}$ \\
\hline Polyubiquitin & $\begin{array}{l}\text { Schizosaccharomyces pombel } \\
\text { AAC64787.1 }\end{array}$ & $3 e-65$ & - & 33 & Protein degradation \\
\hline $\begin{array}{l}\text { Probable type-III integral } \\
\text { membrane protein }(\mathrm{YTP} 1) \dagger\end{array}$ & Aspergillus nidulans/XP_406436.1 & $5 e-25$ & - & 10 & Not defined \\
\hline Serine proteinase ${ }^{\star}$ & $\begin{array}{l}\text { Paracoccidioides brasiliensis/ } \\
\text { AAP } 83193\end{array}$ & $1 \mathrm{e}-85$ & $3.4 .21 .-$ & 14 & Protein degradation \\
\hline $\begin{array}{l}\text { Ubiquitin-conjugating enzyme } \\
\text { E2 }\end{array}$ & Aspergillus nidulans/XP_407263.1 & $1 e-64$ & $6.3 .2 .-$ & 12 & Protein degradation \\
\hline $\begin{array}{l}\text { 3-Dimethylubiquinone-9,3- } \\
\text { methyltransferase }^{*}\end{array}$ & $\begin{array}{l}\text { Coccidioides immitis/ } \\
\text { XP_001248608.1 }\end{array}$ & $6 e-38$ & 2.1 .1 .64 & 20 & Ubiquinone biosynthesis \\
\hline Ferrochelatase $^{\star}$ & Aspergillus nidulans/XP_411889.1 & $3 e-76$ & 4.99 .1 .1 & 10 & $\begin{array}{l}\text { Porphyrin metabolism/Insertion } \\
\text { of iron into haem }\end{array}$ \\
\hline Elongation factor 1-alpha & Coccidioides immitis/AAK54650 & $4 \mathrm{e}-80$ & - & 13 & Protein biosynthesis \\
\hline Histone $\mathrm{H}_{2} \mathrm{~A}^{*}$ & Aspergillus nidulans/XP_412176.1 & $3 e-54$ & - & 19 & Nucleosome assembly \\
\hline Nucleosome assembly protein ${ }^{*}$ & Gibberella zeae/XP_387643.1 & $5 e-55$ & - & 10 & $\begin{array}{l}\mathrm{H} 2 \mathrm{~A} \text { and } \mathrm{H} 2 \mathrm{~B} \text { nucleosome } \\
\text { assembly }\end{array}$ \\
\hline $\begin{array}{l}\text { Small nuclear ribonucleoprotein } \\
\text { U6 }(\operatorname{Lsm} 3)^{\star}\end{array}$ & Aspergillus nidulans/XP_404184.1 & $1 \mathrm{e}-33$ & - & 10 & RNA metabolism/RNA splicing \\
\hline $\begin{array}{l}\text { Transcription factor spt3 } \\
(\mathrm{SPT} 3)^{\star}\end{array}$ & Aspergillus fumigatus/CAF32113 & $3 e-48$ & - & 16 & $\begin{array}{l}\text { Transcription/Assembly of RNA } \\
\text { polymerase }\end{array}$ \\
\hline $\begin{array}{l}\text { Translation initiation factor } \\
\text { subunit Suil }\end{array}$ & Gibberella zeae/XP_389056.1 & $4 \mathrm{e}-49$ & - & 12 & $\begin{array}{l}\text { Protein biosynthesis/Ribosomal } \\
\text { recognition of the initiation } \\
\text { codon }\end{array}$ \\
\hline CAP20-virulence factor ${ }^{\star}$ & Aspergillus nidulans/XP_408358.1 & $3 e-38$ & - & 40 & Not defined \\
\hline
\end{tabular}

${ }^{\star}$ Overexpressed in comparison to the transcriptome of the in vitro-cultured yeast-phase cells (https://dna.biomol.unb.br/Pb/). $\dagger$ Novel genes of P. brasiliensis as defined by comparison to the transcriptome of in vitro-cultured yeast-form cells and to the NCBI database (http:// www.ncbi.nlm.nih.gov/).

probably involved in amino acid pathways (Table 4). Glutamine synthetase catalyses the ATP-dependent conversion of glutamate and ammonium to glutamine. In this context, urease in yeast-form cells could lead to the overproduction of ammonia arising from urea. Analysis of the amino acid metabolism pathways indicated that during the infection process $P$. brasiliensis could independently synthesize asparagine. Imidazole glycerol phosphate synthase catalyses the closure of the imidazole rings within the histidine biosynthesis pathway; this enzyme links amino acid and nucleotide biosynthesis, providing the substrate for de novo purine biosynthesis. 3-Isopropylmalate dehydrogenase catalyses the last step in leucine biosynthesis. The first and a key enzyme in the lysine biosynthesis pathway, homocitrate synthase, is also upregulated. Also lysine uptake should be increased by the overexpression of a lysine-specific permease. Cysteine synthase B could promote thiosulfate assimilation and cysteine could be overproduced by the action of the upregulated transcript encoding cystathionine $\beta$-synthase. The overexpression of the highaffinity methionine permease could promote uptake of methionine and cysteine. Aci-reductone dioxygenase could 
Table 3. KEGG pathway mapping for novel and upregulated genes of $P$. brasiliensis yeast cells recovered from infected mouse liver

\begin{tabular}{|c|c|c|c|c|}
\hline \multirow[t]{2}{*}{ KEGG pathway } & \multicolumn{2}{|c|}{ Number of sequences } & \multicolumn{2}{|c|}{ Percentage of total } \\
\hline & Novel & Upregulated & Novel $^{\star}$ & Upregulated $\dagger$ \\
\hline \multicolumn{5}{|l|}{ Carbohydrate metabolism } \\
\hline Glycolysis/gluconeogenesis & 53 & - & 3.03 & - \\
\hline Pyruvate metabolism & - & 32 & - & 2.73 \\
\hline Pentose phosphate pathway & 3 & - & 0.17 & - \\
\hline Glycogen metabolism & 2 & - & 0.11 & - \\
\hline Citrate cycle (TCA cycle) & - & 24 & - & 2.05 \\
\hline Amino sugar metabolism & - & 16 & - & 1.36 \\
\hline Glyoxylate and dicarboxylate metabolism & - & 13 & - & 1.11 \\
\hline Nucleotide sugar metabolism & - & 12 & - & 1.02 \\
\hline \multicolumn{5}{|l|}{ Energy metabolism } \\
\hline Nitrogen metabolism & 8 & - & 0.46 & - \\
\hline Oxidative phosphorylation & 9 & 99 & 0.51 & 8.45 \\
\hline \multicolumn{5}{|l|}{ Nucleotide metabolism } \\
\hline Purine and pyrimidine metabolism & 5 & 4 & 0.28 & 0.34 \\
\hline \multicolumn{5}{|l|}{ Amino acid metabolism } \\
\hline Tryptophan metabolism & 3 & - & 0.17 & - \\
\hline Alanine and aspartate metabolism & 1 & 9 & 0.06 & 0.77 \\
\hline Glycine, serine and threonine metabolism & - & 11 & - & 0.94 \\
\hline Glutamate metabolism & - & 27 & - & 2.30 \\
\hline Valine, leucine and isoleucine degradation & 2 & 4 & 0.11 & 0.34 \\
\hline Valine, leucine and isoleucine biosynthesis & 1 & 10 & 0.05 & 0.85 \\
\hline Methionine metabolism & - & 4 & - & 0.34 \\
\hline Urea cycle and metabolism of amino groups & - & 7 & - & 0.60 \\
\hline Cysteine metabolism & 1 & - & 0.06 & - \\
\hline \multicolumn{5}{|l|}{ Lipid metabolism } \\
\hline Fatty acid metabolism & 1 & 8 & 0.06 & 0.68 \\
\hline Glycerophospholipid metabolism & 4 & 7 & 0.23 & 0.60 \\
\hline Glycerolipid metabolism & - & 6 & - & 0.51 \\
\hline Linoleic acid metabolism & 2 & - & 0.11 & - \\
\hline Biosynthesis of steroids & 4 & - & 0.23 & - \\
\hline \multicolumn{5}{|l|}{ Metabolism of cofactors and vitamins } \\
\hline Ubiquinone biosynthesis & - & 40 & - & 3.41 \\
\hline Porphyrin and chlorophyll metabolism & - & 10 & - & 0.85 \\
\hline Nicotinate and nicotinamide metabolism & 1 & - & 0.06 & - \\
\hline Folate biosynthesis & - & 8 & - & 0.68 \\
\hline \multicolumn{5}{|l|}{ Cell growth and death } \\
\hline Cell cycle & 1 & - & 0.06 & - \\
\hline \multicolumn{5}{|l|}{ Transcription } \\
\hline RNA polymerase & 8 & 5 & 0.46 & 0.43 \\
\hline \multicolumn{5}{|l|}{ Replication and repair } \\
\hline DNA polymerase & - & 4 & - & 0.34 \\
\hline \multicolumn{5}{|l|}{ Protein folding, sorting and degradation } \\
\hline Ubiquitin-mediated proteolysis & - & 14 & - & 1.19 \\
\hline \multicolumn{5}{|l|}{ Signal transduction } \\
\hline Calcium signalling pathway & - & 6 & - & 0.51 \\
\hline Phosphatidylinositol signalling system & 1 & - & 0.06 & - \\
\hline
\end{tabular}

${ }^{\star}$ Percentage in relation to the total number of novel genes.

$\dagger$ Percentage in relation to the total number of overexpressed genes.

promote the methionine salvage pathway (MTA). Adenylosuccinate lyase, which encodes an enzyme involved in adenylate synthesis, and orotate phosphoribosyltransferase, involved in pyrimidine biosynthesis, are both novel genes. 
Table 4. Overexpressed and novel genes involved in carbohydrate, lipid, amino acid and energy-yielding metabolism in the transcriptome of $P$. brasiliensis yeast-phase cells recovered from livers of infected mice

\begin{tabular}{|c|c|c|c|c|}
\hline Pathway & Gene product & Annotated function & EC no. & Redundancy \\
\hline \multirow{9}{*}{$\begin{array}{l}\text { Carbohydrate synthesis } \\
\text { and degradation }\end{array}$} & Acylphosphatase $(\mathrm{AcP}) \dagger$ & Putative regulator of the glycolytic pathway & 3.6.1.7 & 6 \\
\hline & $\begin{array}{l}\text { Quinoprotein alcohol dehydrogenase } \\
\text { family protein } \dagger\end{array}$ & Alcoholic fermentation & 1.1.99.8 & 7 \\
\hline & Glucokinase $(\mathrm{GLK}) \dagger$ & Carbohydrate metabolism/glycolysis & 2.7.1.2 & 45 \\
\hline & Phosphoglycerate mutase (GPM1P)* & Carbohydrate metabolism/glycolysis & 5.4.2.1 & 13 \\
\hline & Glycogen phosphorylase $1(\mathrm{GPH} 1) \dagger$ & Glycogen breakdown/glycogenolysis & 2.4.1.1 & 2 \\
\hline & $\begin{array}{l}\text { D-ribose-5-phosphate ketol-isomerase } \\
\text { (RIP5) } \dagger\end{array}$ & Pentose phosphate pathway & 5.3.1.6 & 3 \\
\hline & Monosaccharide transporter (MFS1)* & Transport of sugars & - & 9 \\
\hline & Glucose transporter (MFS2) $\dagger$ & Transport of sugars & - & 3 \\
\hline & $\begin{array}{l}\text { Phosphotransferase system, } \\
\text { phosphocarrier HPR protein (PTS) } \dagger\end{array}$ & Transport of sugars & 2.7.3.9 & 2 \\
\hline \multirow{11}{*}{$\begin{array}{l}\text { Lipid/phospholipid } \\
\text { synthesis and } \\
\text { degradation }\end{array}$} & Malic enzyme $(\mathrm{ME})^{\star}$ & $\begin{array}{l}\text { Fatty acid biosynthesis/transfer of acetate } \\
\text { to cytosol }\end{array}$ & 1.1.1.40 & 11 \\
\hline & Carbonic anhydrase $(\mathrm{CA}) \dagger$ & Biosynthesis of bicarbonate & 4.2.1.1 & 11 \\
\hline & Acetyl-CoA carboxylase $(\mathrm{ACC} 1)^{\star}$ & Fatty acid biosynthesis & 6.4.1.2 & 6 \\
\hline & Fatty-acyl-CoA synthase (beta-subunit) ${ }^{\star}$ & Fatty acid biosynthesis & 2.3.1.86 & 8 \\
\hline & $\begin{array}{l}\text { Member of the MBOAT family of } \\
\text { putative membrane-bound } \\
O \text {-acyltransferases (Yor } 175 \mathrm{cp} \text { ) } \dagger\end{array}$ & $\begin{array}{l}\text { Acetyl transferase for phospholipid } \\
\text { biosynthesis }\end{array}$ & 2.3.-.-- & 1 \\
\hline & $\begin{array}{l}\text { Patatin-like serine hydrolase } \\
\text { (phospholipase A2 activity) } \dagger\end{array}$ & Hydrolysis of phospholipids & - & 2 \\
\hline & $\begin{array}{l}\text { Phosphatidic acid-preferring } \\
\text { phospholipase } \mathrm{A} 1 \dagger\end{array}$ & Hydrolysis of phospholipids & 3.1.1.32 & 1 \\
\hline & Delta-9-fatty acid desaturase $(\mathrm{OLE} 1)^{*}$ & $\begin{array}{l}\text { Biosynthesis of monounsaturated fatty } \\
\text { acids }\end{array}$ & 1.14.19.1 & 22 \\
\hline & $\begin{array}{l}\text { Delta(24)-sterol } C \text {-methyltransferase } \\
(\text { ERG6)* }\end{array}$ & Biosynthesis of ergosterol & 2.1.1.41 & 6 \\
\hline & Squalene synthetase (ERG9) $\dagger$ & Biosynthesis of ergosterol & 2.5.1.21 & 1 \\
\hline & Delta 8-sphingolipid desaturase $\dagger$ & Biosynthesis of membrane sphingolipids & 1.14.99.- & 1 \\
\hline \multirow{4}{*}{$\begin{array}{l}\text { TCA cycle and glyoxylate } \\
\text { cycle }\end{array}$} & Isocitrate lyase $(\mathrm{ICL})^{\star}$ & Glyoxylate cycle & 4.1.3.1 & 13 \\
\hline & $\begin{array}{l}\text { Hydroxymethylglutaryl-CoA lyase } \\
(\mathrm{HMGCL})^{\star}\end{array}$ & $\begin{array}{l}\text { Leucine degradation/acetyl-CoA } \\
\text { production }\end{array}$ & 4.1.3.4 & 4 \\
\hline & Carnitine acetyl transferase $(\mathrm{CAT})^{*}$ & $\begin{array}{l}\text { Transport of acetylcarnitine into } \\
\text { mitochondria }\end{array}$ & 2.3.1.7 & 9 \\
\hline & $\begin{array}{l}\text { Carnitine/acylcarnitine translocase } \\
(\mathrm{CACT}) \dagger\end{array}$ & $\begin{array}{l}\text { Transport of acetylcarnitine into } \\
\text { mitochondria }\end{array}$ & 2.3.1.- & 1 \\
\hline \multirow{5}{*}{$\begin{array}{l}\text { Oxidation of NADH and } \\
\text { energy generation }\end{array}$} & ATP synthase $\mathrm{F}_{0} \mathrm{~F}_{1} \mathrm{~J}$ chain ${ }^{\star}$ & Aerobic respiration & 3.6.3.14 & 7 \\
\hline & ATP synthase $\mathrm{F}_{0} \mathrm{~F}_{1}$ subunit $9^{\star}$ & Aerobic respiration & 3.6.3.14 & 88 \\
\hline & ATP synthase $\mathrm{F}_{0} \mathrm{~F}_{1}$ subunit e (TIM111) †† & Aerobic respiration & 3.6.3.14 & 1 \\
\hline & $\begin{array}{l}\text { Cytochrome } c \text { oxidase subunit VIIa } \\
(\mathrm{CCO}) \dagger\end{array}$ & Aerobic respiration & 1.9.3.1 & 6 \\
\hline & $\begin{array}{l}\text { Cytochrome } c \text { oxidase subunit I } \\
(\mathrm{COX} 1) \dagger\end{array}$ & Aerobic respiration & 1.9.3.1 & 4 \\
\hline \multirow[t]{4}{*}{$\begin{array}{l}\text { Nitrogen/amino acid } \\
\text { metabolism }\end{array}$} & Glutamine synthetase (GLNA)* & $\begin{array}{l}\text { Conversion of ammonia and glutamate to } \\
\text { glutamine }\end{array}$ & 6.3 .1 .2 & 11 \\
\hline & Urease $(\mathrm{URE})^{\star}$ & $\begin{array}{l}\text { Hydrolysis of urea to carbon dioxide and } \\
\text { ammonia }\end{array}$ & 3.5.1.5 & 7 \\
\hline & Asparagine synthase (AS) $\dagger$ & $\begin{array}{l}\text { Biosynthesis of L-asparagine from } \\
\text { L-aspartate }\end{array}$ & 6.3 .5 .4 & 1 \\
\hline & $\begin{array}{l}\text { Imidazole glycerol phosphate synthase } \\
\text { HisHF (IGP synthase) } \dagger\end{array}$ & $\begin{array}{l}\text { Histidine biosynthesis/de novo purine } \\
\text { biosynthesis }\end{array}$ & 2.4.2.- & 1 \\
\hline
\end{tabular}


Table 4. cont.

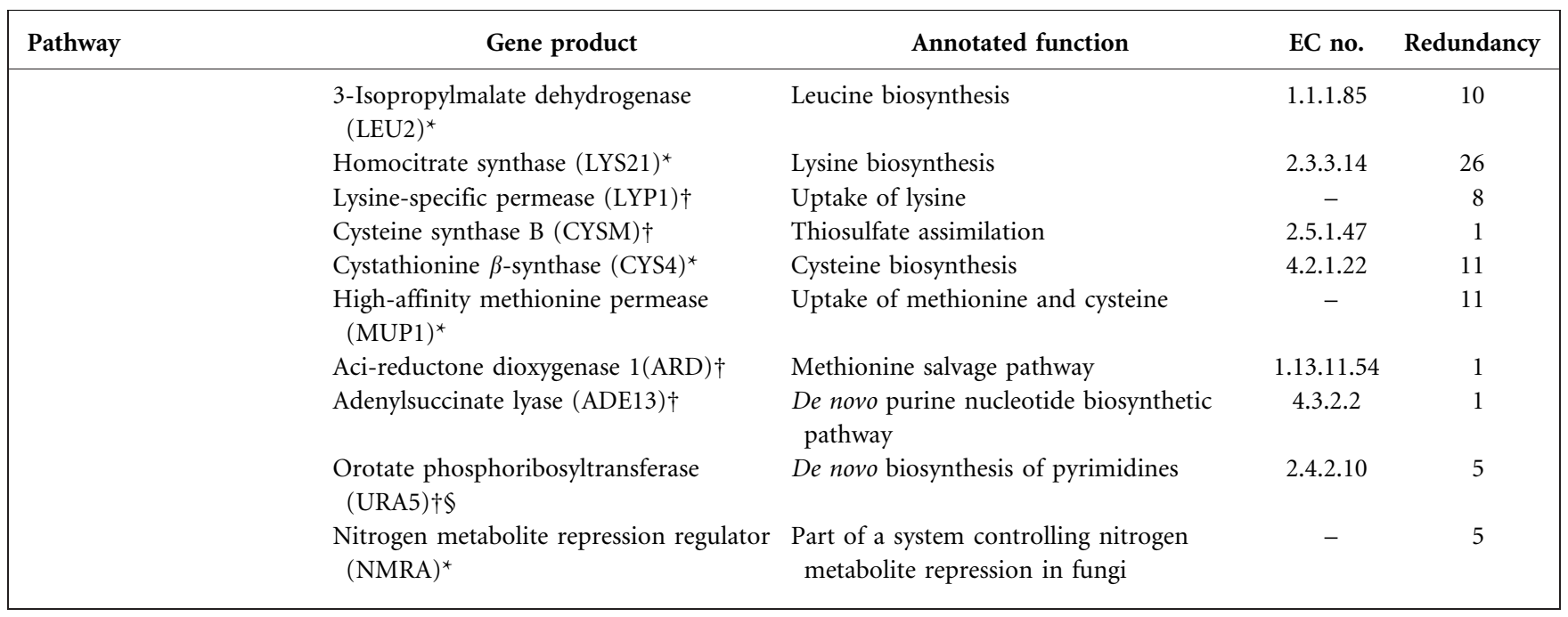

${ }^{*}$ Overexpressed genes identified in $P$. brasiliensis transcriptome of yeast-phase cells recovered from infected mouse liver.

$\dagger$ Novel genes identified in P. brasiliensis transcriptome of yeast-phase cells recovered from infected mouse liver.

\$Genes not described previously in P. brasiliensis isolate Pb01, but present in public databases.

$\S$ Novel transcripts also detected in a P. brasiliensis dimorphic transition transcriptome (Bastos et al., 2007).

\section{Validation of the ESTs by PCR analysis and expression of selected genes in yeast-phase cells recovered from infected mice and in an ex vivo model}

We initially validated five novel genes by PCR analysis of $P$. brasiliensis genomic DNA, as shown in Fig. 2(a). The novel genes encoding indigoidine synthase A-like protein (indA), oligopeptide transporter protein (opt), Rho guanyl exchange factor (gef), oxidation resistance protein (oxr1) and glucokinase $(g l k)$ were demonstrated to be present in the genome of $P$. brasiliensis. In the next series of experiments, confirmatory data regarding the expression levels from EST redundancy analysis were provided by sqRT-PCR analysis. Transcripts encoding carbonic anhydrase (ca), myosin 2 isoform (myo2), telomerase reverse transcriptase (tert), poly(A) polymerase (pap1), orotate phosphoribosyltransferase (ura5) and patatin-like serine hydrolase ( $p a t$ ) were confirmed as being present at higher levels in yeast-form cells recovered from infected mouse livers (Fig. 2b). Also, some novel transcripts were validated by sqRT-PCR of RNAs obtained from yeast forms interacting with in vitro-cultured Vero cells. The novel transcripts encoding $c a, m y o 2$, tert, pap1, pat, squalene synthetase (erg9), oxr1 and $g l k$ were present in yeast cells in the ex vivo model (Fig. 3).

\section{DISCUSSION}

Here we report in silico analysis and comparison of ESTs from yeast-form cells of $P$. brasiliensis recovered from infected mouse livers with previously described $P$. brasiliensis transcriptomes. The expression profiles of genes encoding enzymes involved in primary metabolism show that there is a striking degree of coordinate regulation of some of the genes in the same pathway. For example, genes encoding enzymes, regulators and transporters in carbohydrate metabolism are significantly overexpressed in fungal cells recovered from infected tissue. Transcripts of genes involved in lipid synthesis are also expressed at high levels.

A great number of induced and novel genes in yeast-form cells recovered from liver were involved in carbohydrate metabolism. In a previous study, comparing mRNA expression of mycelia and yeast-phase cells, Felipe et al. (2005) suggested that the metabolism of yeast-form cells is more anaerobic than that of mycelium toward the production of ethanol. Our data suggest that infection of liver by $P$. brasiliensis yeast-form cells exacerbates their anaerobic behaviour, when compared to in vitro-cultured yeast-form cells. There is actually an increase in mRNA expression of several genes involved in glycolysis. Corroborating our data, a glucokinase gene of Saccharomyces cerevisiae has been shown previously to be overexpressed under conditions of ethanol induction (Herrero et al., 1999). Although the physiological role of acylphosphatase is as yet unknown, the enzyme plays a part in the regulation in the glycolytic pathway, by increasing the rate of glucose fermentation in yeast (Raugei et al., 1996). The predicted upregulation of glycolysis in $P$. brasiliensis described here is corroborated by a previous description of the predominance of glycolytic metabolism in Candida albicans colonizing mouse tissues (Barelle et al., 2006). Additionally, the emphasis on the overexpression of these enzymes of carbohydrate metabolism suggests that the milieu may provide an adequate nutritional environment 

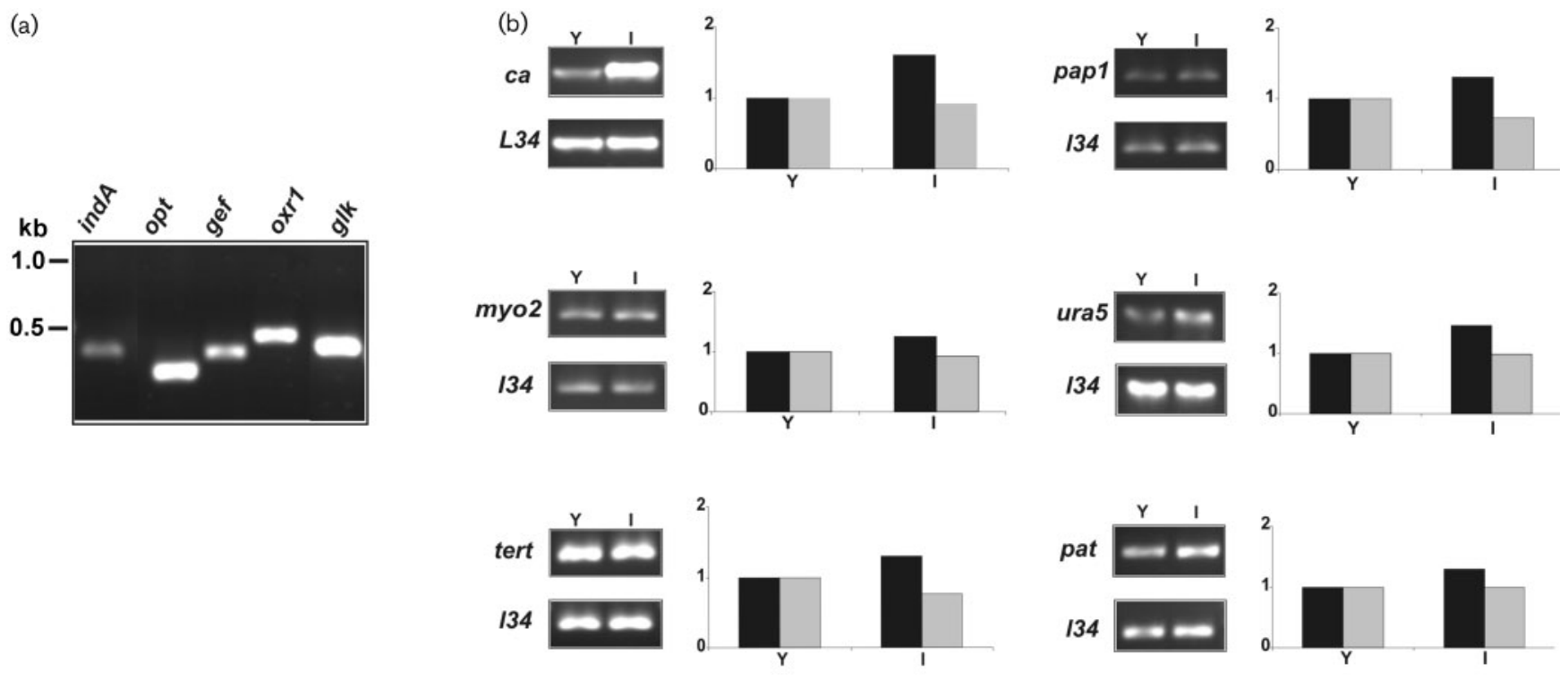

Fig. 2. Validation of the cDNA library for the presence of genes and analysis of redundancy of some transcripts. PCR and sqRT-PCR analysis were carried out with specific sense and antisense oligonucleotide primers, respectively, as described in Table 1. (a) PCR of total genomic DNA of $P$. brasiliensis with specific primers. (b) SqRT-PCR of RNAs from yeast-phase cells. The RNA samples were obtained from yeast-phase cells, in vitro cultured (Y); and yeast-phase cells recovered from livers of infected mice (I). The bar diagrams indicate fold differences relative to the data for the reference in vitro-cultured yeast cells: control reactions with the ribosomal L34 protein are indicated by grey bars; black bars indicate the reactions for the selected genes. The sizes of the amplified products are listed in Table 1.

to enable the the glycolytic pathway to be shifted toward the production of ethanol, a metabolic pathway that should be particularly important during liver infection because of abundant glucose in this host milieu.

Ethanol could become a relevant carbon source by entering the glyoxylate cycle, which has been previously described as being upregulated in fungal yeast-phase cells (Felipe et al., 2005). The cycle may be more active in yeast-form cells infecting mouse liver, as demonstrated here by the overexpression of the regulatory enzyme isocitrate lyase, suggesting that some non-fermentable compounds are important for energy production during infection as described previousy for fungi such as Candida albicans and Cryptococcus neoformans (Lorenz \& Fink, 2001; Ramírez \& Lorenz, 2007; Rude et al., 2002). Interestingly, the isocitrate lyase gene of Penicillium marneffei has been shown previously to be strongly induced at $37{ }^{\circ} \mathrm{C}$, even in the presence of a repressing carbon source, such as glucose (Cánovas \& Andrianopoulos, 2006), a condition occurring in liver.

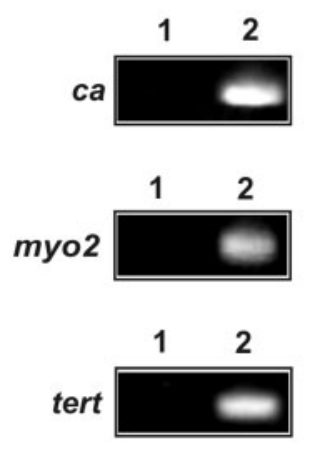

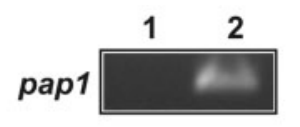
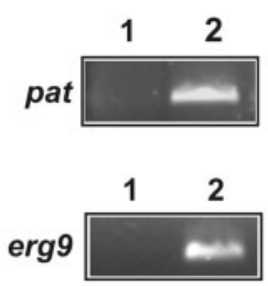
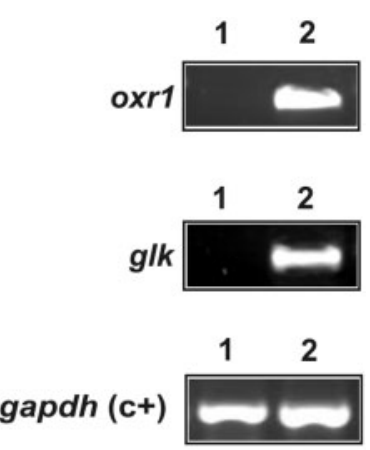

Fig. 3. Transcript analysis of the interaction of $P$. brasiliensis with Vero cells: sqRT-PCR analysis of selected transcripts in yeast-phase cells in the ex vivo model of infection. Lane 1, detection of transcripts in control Vero cells; lane 2, detection of transcripts in $P$. brasiliensis yeast forms infecting Vero cells. The sizes of the amplified products are given in Table 1. The gene encoding GAPDH was used as an internal control for Vero cells. 
The biosynthesis of lipids may be upregulated during the infection process. The overexpression of transcripts encoding lipogenic enzymes corroborates this suggestion. Fatty acid synthesis is maximal when carbohydrate and energy are plentiful, a condition believed to occur in liver. Regarding carbonic anhydrase, previous studies have demonstrated that this enzyme's activity is required for C. neoformans fatty acid biosynthesis (Bahn et al., 2005). It has not escaped our attention that the increase in carbonic anhydrase mRNA may reflect the high $\mathrm{CO}_{2}$ levels in the host tissue.

Membrane composition seems to change during infection. Ergosterol is the major sterol in fungal membranes and affects their fluidity and permeability. Transcripts encoding ERG6 and ERG9 were differentially regulated. Also increased were the mRNA levels for enzymes related to the synthesis and remodelling of the cell membrane, such as OLE1, involved in regulating membrane fluidity in animal cells and micro-organisms (Gargano et al., 1995), and responsible for the adjustments in the membrane composition in response to nutritional change (Vigh et al., 1998).

P. brasiliensis seems to perform oxidative phosphorylation by classical pathways during infection. Of special note is the huge overexpression of the ATP synthase $\mathrm{F}_{0} \mathrm{~F}_{1}$ subunit 9 , the relevance of which is not clear.

Nitrogen metabolism is one aspect of basic metabolism which is still quite unknown in the field of pathogenesis. The most critical genes for $S$. cerevisiae in vivo survival were found to be those required for amino acid biosynthesis (Kingsbury et al., 2006). We described here 14 novel/ overexpressed genes related to the metabolism of amino acids, suggesting that this aspect of metabolism should be very relevant to fungal survival in the host liver environment. Among the genes were those encoding several metabolic steps in biosynthesis of amino acids, as well as the transcriptional regulator NMRA gene, encoding a predictable nitrogen metabolite repressor, suggesting that $P$. brasiliensis is subject to nitrogen metabolite repression under host conditions, probably reflecting ammonia and glutamine availability in liver.

It can be suggested, on the basis of the transcriptional data provided by this study, that increased glutamine, asparagine, histidine, lysine, cysteine and methionine biosynthesis are important for the survival of $P$. brasiliensis during infection. Glutamine formation plays a key role in nitrogen metabolism, ensuring the reassimilation of nitrogen released from cellular processes and providing the source of amino groups in a wide range of biosynthetic processes. Our analysis indicated that during infection $P$. brasiliensis seems to be able to synthesize asparagine, providing, in addition to glutamine, another site for transient storage of nitrogen. The novel transcript encoding aci-reductone dioxygenase suggests the presence of the methionine salvage pathway cycle (Hirano et al., 2005) providing additional methionine, which could be scarce in the host environment. Overall, the presumed increase in synthesis of the amino acids listed above implies that those compounds are not present at sufficient levels in host tissue to support growth of $P$. brasiliensis.

To obtain further corroboration of the validity of our EST results, we performed RT-PCR analysis of some selected transcripts in yeast cells recovered from infected tissue in a different series of experiments from those used to construct the cDNA library, as well as in an ex vivo model of infection. Several novel transcripts, such as those encoding glucokinase and carbonic anhydrase, were confirmed, further corroborating the validity of our EST analysis and suggesting the relevance of those transcripts in the infectious process.

Importantly, several of the genes identified in this work had previously been implicated in pathogenesis in other organisms. The most important types of melanin in fungi are DHN-melanin and DOPA-melanin, which have been implicated in pathogenesis (Hamilton \& Gomez, 2002). Transcripts encoding aromatic L-amino acid decarboxylase were abundant in yeast-phase cells under our experimental conditions, reinforcing the relevance of DOPA-melanin in infection, as suggested elsewhere (Gomez et al., 2001; Silva et al., 2006; Bailão et al., 2006). Polyketide synthase is a novel transcript, suggesting that $P$. brasiliensis could synthesize melanin via the polyketide synthase pathway, as described previously for other fungi (Paolo et al., 2006). Candida albicans carbonic anhydrase mutants cannot induce true hyphae in response to high $\mathrm{CO}_{2}$, a condition of induction of filamentation (Klengel et al., 2005). Tissue damage and dissemination by Coccidioides involve the ammonia-based alkalinization of the host environment through the activity of fungal urease (Mirbod-Donovan et al., 2006). The oxidation resistance (OXR1) protein is involved in protection of cells from oxidative hydrogen peroxide damage (Elliott \& Volkert, 2004). The gene encoding orotate-5-monophosphate pyrophosphorylase in Histoplasma capsulatum is essential for fungal virulence in a mouse infection model (Retallack et al., 1999). These findings further encourage the study of the relevance of these genes to $P$. brasiliensis pathogenesis.

In summary our data suggest that $P$. brasiliensis probably uses multiple carbon sources during liver infection, including glucose and substrates of the glyoxylate cycle. In addition, the metabolism of nitrogen can be very active during the infection process, suggesting that, while some nitrogenous compounds can be preferentially acquired from the host, others must be supplemented by the pathogen. Also, the biosynthesis of lipids appears to be very active, suggesting the plentiful availability of carbohydrates and energy.

\section{ACKNOWLEDGEMENTS}

This work was supported by grants from Conselho Nacional de Desenvolvimento Científico e Tecnológico (CNPq). The authors 
thank Laboratório Nacional de Computação Científica (LNCC) for bioinformatics support.

\section{REFERENCES}

Ahren, D., Troein, C., Johansson, T. \& Tunlid, A. (2004). PHOREST: a web-based tool for comparative analyses of expressed sequence tag data. Mol Ecol Notes 4, 311-314.

Altschul, S. F., Madden, T. L., Schaffer, A. A., Zhang, J., Zhang, Z., Miller, W. \& Lipman, D. J. (1997). Gapped BLAST and PSI-BLAST: a new generation of protein database search programs. Nucleic Acids Res 25, 3389-3402.

Audic, S. \& Claverie, J. M. (1997). The significance of digital gene expression profiles. Genome Res 7, 986-995.

Bahn, Y. S., Cox, G. M., Perfect, J. R. \& Heitman, J. (2005). Carbonic anhydrase and $\mathrm{CO}_{2}$ sensing during Cryptococcus neoformans growth, differentiation, and virulence. Curr Biol 15, 2013-2020.

Bailão, A. M., Schrank, A., Borges, C. L., Dutra, V., Molinari-Madlum, E. E. W. I., Felipe, M. S. S., Mendes-Giannini, M. J. S., Martins, W. S., Pereira, M. \& Soares, C. M. A. (2006). Differential gene expression by Paracoccidioides brasiliensis in host interaction conditions: representational difference analysis identifies candidate genes associated with fungal pathogenesis. Microbes Infect 8, 2686-2697.

Barelle, C. J., Priest, C. L., MacCallum, D. M., Gow, N. A. R., Odds, F. C. \& Brown, A. J. P. (2006). Niche-specific regulation of central metabolic pathways in a fungal pathogen. Cell Microbiol 8, 961-971.

Bastos, K. P., Bailão, A. M., Borges, C. L., Faria, F. P., Felipe, M. S. S., Silva, M. G., Martins, W. S., Fiúza, R. B., Pereira, M. \& Soares, C. M. A. (2007). The transcriptome analysis of early morphogenesis in Paracoccidioides brasiliensis mycelium reveals novel and induced genes potentially associated to the dimorphic process. BMC Microbiol 7, 29.

Cánovas, D. \& Andrianopoulos, A. (2006). Developmental regulation of the glyoxylate cycle in the human pathogen Penicillium marneffei. Mol Microbiol 62, 1725-1738.

Elliott, N. A. \& Volkert, M. R. (2004). Stress induction and mitochondrial localization of Oxr1 proteins in yeast and humans. Mol Cell Biol 24, 3180-3187.

Ewing, B. \& Green, P. (1998). Base-calling of automated sequencer traces using Phred. II. Error probabilities. Genome Res 8, 186-194.

Felipe, M. S. S., Andrade, R. V., Petrofeza, S. S., Maranhao, A. Q., Torres, F. A., Albuquerque, P., Arraes, F. B., Arruda, M., Azevedo, M. O. \& other authors (2003). Transcriptome characterization of the dimorphic and pathogenic fungus Paracoccidioides brasiliensis by EST analysis. Yeast 20, 263-271.

Felipe, M. S. S., Andrade, R. V., Arraes, F. B. M., Nicola, A. M., Maranhão, A. Q., Torres, F. A. G., Silva-Pereira, I., Poças-Fonseca, M. J., Campos, E. G. \& other authors (2005). Transcriptional profiles of the human pathogenic fungus Paracoccidioides brasiliensis in mycelium and yeast cells. J Biol Chem 280, 24706-24714.

Gargano, S., Di Lallo, G., Kobayashi, G. S. \& Maresca, B. (1995). A temperature-sensitive strain of Histoplasma capsulatum has an altered delta 9-fatty acid desaturase gene. Lipids 30, 899-906.

Goldman, G. H., dos Reis Marques, E., Duarte Ribeiro, D. C., de Souza Bernardes, L. A., Quiapin, A. C., Vitorelli, P. M., Savoldi, M., Semighini, C. P., de Oliveira, R. C. \& other authors (2003). Expressed sequence tag analysis of the human pathogen Paracoccidioides brasiliensis yeast phase: identification of putative homologues of Candida albicans virulence and pathogenicity genes. Eukaryot Cell 2, 34-48.

Gomez, B. L., Nosanchuk, J. D., Diez, S., Youngchim, S., Aisen, P., Cano, L. E., Restrepo, A., Casadevall, A. \& Hamilton, A. J. (2001)
Detection of melanin-like pigments in the dimorphic fungal pathogen Paracoccidioides brasiliensis in vitro and during infection. Infect Immun 69, 5760-5767.

Hamilton, A. J. \& Gomez, B. L. (2002). Melanins in fungal pathogens. J Med Microbiol 51, 189-191.

Herrero, P., Flores, L., de la Cera, T. \& Moreno, F. (1999). Functional characterization of transcriptional regulatory elements in the upstream element of the yeast GLK1 gene. Biochem J 343, 319-325.

Hirano, W., Gotoh, I., Uekita, T. \& Seiki, M. (2005). Membrane-type 1 matrix metalloproteinase cytoplasmic tail binding protein-1 (MTCBP-1) acts as an eukaryotic aci-reductone dioxygenase (ARD) in the methionine salvage pathway. Genes Cells 10, 565-574.

Huang, X. \& Madan, A. (1999). CAP3: a DNA sequence assembly program. Genome Res 9, 868-877.

Kingsbury, J. M., Goldstein, A. L. \& McCusker, J. H. (2006). Role of nitrogen and carbon transport, regulation and metabolism genes for Saccharomyces cerevisiae survival in vivo. Eukaryot Cell 5, 816-824.

Klengel, T., Liang, W. J., Chaoupka, J., Ruoff, C., Schröppel, K., Naglik, J. R., Eckert, S. E., Mogensen, E. G., Haynes, K. \& other authors (2005). Fungal adenyl cyclase integrates $\mathrm{CO}_{2}$ sensing with cAMP signaling and virulence. Curr Biol 15, 2021-2026.

Lorenz, M. C. \& Fink, G. R. (2001). The glyoxylate cycle is required for fungal virulence. Nature 412, 83-86.

Marques, E. R., Ferreira, M. E., Drummond, R. D., Felix, J. M., Menossi, M., Savoldi, M., Travassos, L. R., Puccia, R., Batista, W. L. \& other authors (2004). Identification of genes preferentially expressed in the pathogenic yeast phase of Paracoccidioides brasiliensis, using suppression subtraction hybridization and differential macroarray analysis. Mol Genet Genomics 271, 667-677.

Mendes-Giannini, M. J., Andreotti, P. F., Vincenzi, L. R., da Silva, J. L., Lenzi, H. L., Benard, G., Zancope-Oliveira, R., de Matos Guedes, H. L. \& Soares, C. P. (2006). Binding of extracellular matrix proteins to Paracoccidioides brasiliensis. Microbes Infect 8, 1550-1559.

Mirbod-Donovan, F., Schaller, R., Hung, C. Y., Xue, J., Reichard, U. \& Cole, G. T. (2006). Urease produced by Coccidioides posadassi contributes to the virulence of this respiratory pathogen. Infect Immun 74, 504-515.

Montenegro, M. R. \& Franco, M. (1994). Pathology. In Paracoccidioidomycosis, pp. 131-150. Edited by M. Franco, C. S. Lacaz, A. Restrepo-Moreno \& G. Del Negro. Boca Raton: CRC.

Nunes, L. R., Oliveira, R. C., Leite, D. B., Silva, V. S., Marques, E. R., Ferreira, M. E. S., Ribeiro, D. C., Bernardes, L. A. S., Goldman, M. H. \& other authors (2005). Transcriptome analysis of Paracoccidioides brasiliensis cells undergoing mycelium-to-yeast transition. Eukaryot Cell 4, 2115-2128.

Paolo, W. F., Jr, Dadachova, E., Mandal, P., Casadevall, A., Szaniszlo, P. J. \& Nosanchuk, J. D. (2006). Effects of disrupting the polyketide synthase gene WdPKS1 in Wangiella [Exophiala] dermatitidis on melanin production and resistance to killing by antifungal compounds, enzymatic degradation, and extremes in temperature. $B M C$ Microbiol 6, 55.

Ramírez, M. A. \& Lorenz, M. C. (2007). Mutations in alternative carbon utilization pathways in Candida albicans attenuate virulence and confer pleiotropic phenotypes. Eukaryot Cell 6, 280-290.

Raugei, G., Modesti, A., Magherini, F., Marzocchini, R., Vecchi, M. \& Ramponi, G. (1996). Expression of acylphosphatase in Saccharomyces cerevisiae enhances ethanol fermentation rate. Biotechnol Appl Biochem 23, 273-278.

Restrepo, A., McEwen, J. G. \& Castaneda, E. (2001). The habitat of Paracoccidioides brasiliensis: how far from solving the riddle? Med Mycol 39, 233-241. 
Retallack, D. M., Heinecke, E. L., Gibbons, R., Deepe, G. S., Jr \& Woods, J. P. (1999). The URA5 gene is necessary for Histoplasma capsulatum growth during infection of mouse and human cells. Infect Immun 67, 624-629.

Rude, T. H., Tolfaletti, D. L., Cox, G. M. \& Perfect, J. R. (2002). Relationship of the glyoxylate pathway and pathogenesis of Cryptococcus neoformans. Infect Immun 70, 5684-5694.

Silva, M. B., Marques, A. F., Nosanchuk, J. D., Casadevall, A., Travassos, L. R. \& Taborda, C. P. (2006). Melanin in the dimorphic fungal pathogen Paracoccidioides brasiliensis: effects on phagocytosis, intracellular resistance and drug susceptibility. Microbes Infect 8, 197-205.

Vigh, L., Maresca, B. \& Horwood, J. L. (1998). Does the membrane's physical state control the expression of the heat shock and other genes? Trends Biochem Sci 23, 369-374.

Edited by: D. Sanglard 